\title{
Pengaruh VCT Terhadap Pengetahuan Tentang Asupan Gizi Dan Perilaku Seksual Kelompok Transpuan
}

\author{
Riezky Faisal Nugroho ${ }^{1^{*}}$, Erika Martining Wardan ${ }^{2}$ \\ ${ }^{1}$ Poltekkes Kemenkes Surabaya, Indonesia \\ 2Universitas Nahdlatul Ulama Surabaya, Indonesia \\ *Korespondensi: riifan7@gmail.com
}

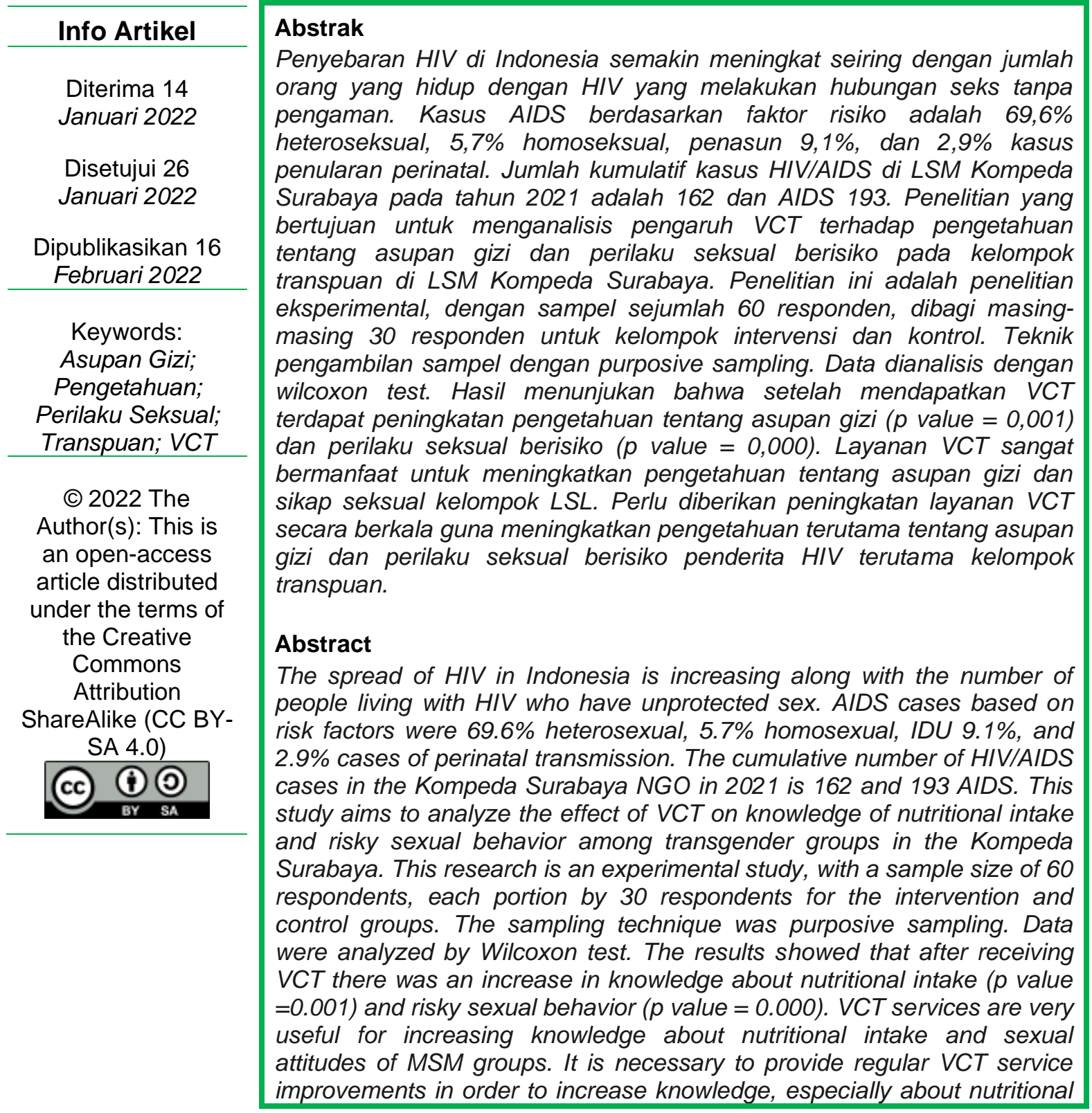


intake and risk sexual behavior of HIV sufferers, especially the trans woman group.

\section{Pendahuluan}

Indonesia merupakan salah satu negara Asia dengan epidemi HIV dan AIDS, prevalensinya meningkat drastis, dan upaya pengendalian sudah dilakukan masyarakat (LSM), sektor swasta, maupun pemerintah, namun tidak menurun. Epidemi pada kasus HIV dan AIDS di Indonesia akan terus meningkat hingga akhir tahun 2021, juga dari sisi konsentrasi pada populasi paling rentan (mARP). Situasi ini memfasilitasi program pencegahan dan pengelolaan HIV dan AIDS untuk mARP, termasuk komunitas LSL (Wardani, dkk, 2020).

Seluruh dunia mencatat prevalensi transpuan di sekitar $10 \%$ atau 750 juta dari 7,5 milyar penduduk di seluruh dunia. Negara pertama dengan jumlah transpuan terbesar adalah Amerika Serikat, juga merupakan negara pertama di tahun 2015 yang melegalkan pernikahan sesama jenis (ConQ, 2015). Data dari Routers, Centers for Disease Control and Prevention (CDC) telah mendata ada 1,1 juta orang di Amerika yang menderita HIV. CDC mengungkap 4\% pria transpuan yang berperilaku seksual menyimpang maka telah menyumbang $66 \%$ infeksi baru di negara tersebut. Salah satu negara berkembang kelima di Asia dengan risiko tinggi terpapar HIV/AIDS adalah Indonesia, dimana jika seseorang dalam tubuhnya terdapat virus ini jika tidak mendapatkan pengobatan ARV akan dapat menyebabkan kematian (Kemenkes RI, 2020). Banyak kelompok yang berisiko terkena HIV, salah satunya adalah transpuan karena sering perperilaku berisiko dengan pasangan yang bergonta ganti (Carmelita, et al., 2017). Kasus HIV/AIDS di Jawa Timur tercatat 18.243 penderita. Mayoritas risiko terpapar HIV tercatat $69,6 \%$ akibat hubungan seks berisiko yaitu heteroseksual, penasun 9,1\%, homoseks $5,7 \%$ dan penularan secara perinatal 2,9\% (Kemenkes, 2018). Komisi penanggulangan AIDS Kota Surabaya berhasil melakukan pemetaan terhadap kasus HIV/AIDS pada tahun 2011 terhadap 5 (lima) kelompok berisiko diantaranya terdapat WPS tercatat 2.975 orang, pelanggan WPS 1.577, Waria 640, transpuan 1325 dan Penasun 767.

Nutrisi ODHA bervariasi tergantung pada kondisi individu dan tingkat keparahan penyakitnya. Pemenuhan kebutuhan gizi yang dapat dicapai dari makanan sehari-hari dikonsumsi oleh ODHA. Di sisi lain, orang yang hidup dengan HIV sangat membutuhkan lebih banyak vitamin dan mineral. Vitamin dan mineral ini bekerja untuk meningkatkan kemampuan tubuh melawan pertumbuhan HIV di dalam tubuh. Infeksi HIV menyebabkan anoreksia dan gangguan arbsorbsi nutrisi yang berdampak gizi buruk pada ODHA. Hubungan yang bermakna antara klinis penderita HIV/AIDS dengan status gizi. Stadium klinis secara tidak langsung mempengaruhi jumlah CD4, yaitu dengan mengganggu absorbs nutrisi akibatnya penderita mengalami gizi yang buruk yang disebabkan karena infeksi oportunistik yang berada dalam tubuh penderita ODHA (Dewi, 2017).

Menurut Wardani, dkk, (2020), kehidupan LSL banyak didominasi oleh sikap seks dan relasi seks mengakibatkan LSL berisiko tinggi terpapar IMS, bahkan lebih tinggi resikonya apabila dibandingkan dengan WPS. Penularan HIV/AIDS bukan didasarkan pada strata, tetapi atas sikap seksual berisiko yang dilakukan. Perilaku 
seksual yang dilakukan melalui lubang anus (anal seks) berisiko sangat tinggi untuk saling menularkan (jika telah tertular) HIV/AIDS, khususnya jika perilaku seksual dilakukan tanpa menggunakan pengaman (kondom).

Menurut Rahmartani, dkk, (2012), salah satu upaya preventif transmisi HIV adalah dengan program VCT (Voluntary Counseling and Testing) yang bertujuan agar seorang individu yang memiliki perilaku berisiko mengetahui kondisi kesehatan sejak dini, serta secara psikologi bisa mencegah perburukan kondisi individu apabila pemeriksaan didapatkan hasil positif. VCT beguna juga bagi individu yang sedang mencari informasi yang komplit tentang HIV atau membantu seseorang mencari pelayanan dan bantuan sesuai yang diinginkan. Berdasarkan masalah diatas, maka peneliti ingin menganalisis tentang "Pengaruh VCT terhadap pengetahuan tentang asupan gizi dan perilaku seksual berisiko pada kelompok transpuan di LSM Kompeda Surabaya".

\section{Metode Penelitian}

Penelitian ini merupakan peneleitian quasi experiment yang menggunakan rancangan penelitian nonrandomized pretest- postest control group design. Penelitian dilakukan pada penderita yang datang ke LSM Kompeda Surabaya selama satu bulan. Kriteria inklusi dalam penelitian ini yaitu penderita HIV/AIDS yang bersedia menjadi responden dan termasuk kelompok transpuan. Kriteria eksklusi dalam penelitian ini adalah kelompok transpuan yang sebelumnya telah mendapatkan layanan VCT sebelum dilakukan penelitian. Teknik pengambilan sampel dengan purposive sampling.

Data terkumpul kemudian diolah langkah dan tahap akhir data dianalisi menggunakan uji statistik Wilcoxon Signed Ranks Test dengan program SPSS versi 23,0 for windows dengan tingkat signifikan $\alpha=0,05$. Apabila hasil uji tersebut menunjukkan $p<\alpha \quad 0,05$ maka hipotesis ditolak yang artinya ada pengaruh antara variable yang diteliti.

\section{Hasil}

Tabel 1 Karakteristik responden

\begin{tabular}{cccc}
\hline No & Variabel & $\begin{array}{c}\text { Jumlah } \\
(\mathrm{n}=60)\end{array}$ & $\begin{array}{c}\text { Prosentase } \\
(\%)\end{array}$ \\
\hline 1. & & 28,3 \\
\hline & Usia (tahun) & 17 & 71,7 \\
\hline 2. & $17-25$ & 43 & 3,3 \\
\hline & $26-45$ & 2 & 75 \\
\hline & Pendidikan & 21,7 \\
\hline 3. & 45 & 71,7 \\
\hline & Sekolah Dasar & 13 & 28,3 \\
\hline & Sekolah Menengah & & 38,3 \\
\hline 4. & Perguruan Tinggi & 43 & 61,7 \\
\hline & Belum menikah & 17 & 11,7 \\
\hline 5. & Menikah & & 88,3 \\
\hline & Pekerjaan & 23 & \\
\hline & Belum bekerja & 37 & \\
\hline & Sudah bekerja & 7 & \\
\hline
\end{tabular}


Berdasarkan tabel 1 diperoleh hasil bahwa responden mayoritas berusia 2645 tahun $(71,7 \%)$, dengan pendidikan di sekolah menengah $(75 \%)$, responden sebagian besar belum menikah $(71,7 \%)$, sudah bekerja $(61,7 \%)$, serta sebagian besar sudah sirkumsisi $(88,3 \%)$

Tabel 2 Pengaruh VCT terhadap pengetahuan tentang asupan gizi

\begin{tabular}{|c|c|c|c|c|c|c|c|}
\hline \multirow[t]{2}{*}{ Kelompok } & \multirow[t]{2}{*}{$n$} & \multicolumn{2}{|c|}{ Sebelum VCT } & \multirow[t]{2}{*}{$p$ value } & \multicolumn{2}{|c|}{ Setelah VCT } & \multirow[t]{2}{*}{$p$ value } \\
\hline & & Mean & SD & & Mean & SD & \\
\hline Intervensi & 30 & 2,50 & 0,630 & 0,107 & 3,00 & 0,000 & 0,001 \\
\hline Kontrol & 30 & 2,70 & 0,466 & & 2,77 & 0,430 & \\
\hline
\end{tabular}

Berdasarkan tabel diatas terlihat bahwa terdapat pengaruh VCT. Berdasarkan uji Wilcoxon didapatkan $p$ value $0,001 \quad(p<0,05)$ maka dapat disimpulkan bahwa Ha diterima yang artinya ada pengaruh yang signifikan tingkat pengetahuan tentang asupan gizi sebelum dan setelah diberikan layanan VCT.

Tabel 3 Pengaruh VCT terhadap pengetahuan tentang perilaku seksual berisiko

\begin{tabular}{|c|c|c|c|c|c|c|c|}
\hline \multirow{2}{*}{ Kelompok } & \multirow[t]{2}{*}{$n$} & \multicolumn{2}{|c|}{ Sebelum VCT } & \multirow{2}{*}{$p$ value } & \multicolumn{2}{|c|}{ Setelah VCT } & \multirow{2}{*}{$p$ value } \\
\hline & & Mean & SD & & Mean & SD & \\
\hline Intervensi & 30 & 2,70 & 0,568 & 2,82 & 2,77 & 0,583 & 0,000 \\
\hline Kontrol & 30 & 2,77 & 0,651 & & 2,73 & 0,568 & \\
\hline
\end{tabular}

Terlihat di table 3 ditemukan adanya pengaruh VCT. Hasil uji Wilcoxon diperoleh hasil $p$ value $0,000 \quad(p<0,05)$, kesimpulannya Ha diterima, artinya terdapat pengaruh tingkat pengetahuan tentang perilaku seksual berisiko sebelum dan setelah diberikan layanan VCT pada kelompok transpuan.

\section{Pembahasan}

\subsection{Karakteristik transpuan}

a. Berdasarkan usia

Hasil penelitian yang diperoleh oleh peneliti adalah responden yang merupakan kelompok transpuan mayoritas berusia 26-45 tahun. Hal ini juga telah dilakukan dengan penelitian yang sama oleh Lubis (2012), pada penelitiannya bahwa usia penyumbang terbesar untuk kasus HIV/AIDS yaitu pada usia dewasa (>24 tahun). Penelitian serupa juga dilakukan oleh Hutapea, et al, (2012), yang menunjukan hasil bahwa penderita HIV/AIDS terdiagnosa pada usia 25 tahun yang berarti penderita tersebut telah terinfeksi virus HIV pada remaja saat berusia 1517 tahun. Hal ini memperlihatkan gejala klinisnya sejak terinfeksi pertama kali membutuhkan waktu 8-10 tahun. Kejadian HIV pada kelompok transpuan berdasarkan rentang usia 26-45 tahun karena kelompok ini merupakan kelompok usia produktif dan juga aktif secara seksual yang juga perlu mendapatkan perhatian khusus.

\section{b. Berdasarkan pendidikan}

Hasil penelitian diperoleh peneliti bahwa responden transpuan mayoritas memiliki latar belakang pendidikan adalah sekolah menengah. Hal ini mendapatkan dukungan dari penelitian sejenis yang dilakukan oleh Luthfiana (2012) yang menemukan kategori umur di bawah 29 tahun merupakan kelompok orang risiko tinggi terinfeksi HIV dan AIDS. Seiring dengan perkembangan HIV dan AIDS, kelompok tertentu ditemukan lebih rentan memiliki perilaku seksual berisiko terhadap HIV dan AIDS. Penelitian terkait juga telah dilakukan oleh Wardani 
(2020), dimana hasil penelitiannya ditemukan bahwa tingkat Pendidikan terakhir seperti SMA termasuk kelompok mayoritas berisiko terinfeksi HIV terbanyak. Hal serupa pada tahun 2012 pada kelompok beresiko pada tahun 2013 telah tercatat sebagian besar berpendidikan terakhir SMA/ sederajat berlsiko tepapar HIV yang tercatat dalam laporan STBP.

Pendidikan seseorang yang cukup baik maka akan tebentuk proses pertumbuhan, perkembangan, dan transformasi menjadi individu, kelompok, atau masyarakat yang lebih matang dan lebih baik. Masyarakat yang berpendidikan tinggi harus mampu memahami informasi terutama terkait HIV/AIDS (Notoadmojo, 2017). Tingkat pendidikan seseorang mempengaruhi kemampuannya untuk memiliki pengetahuan dan memahami informasi yang diterima. Pendidikan mempengaruhi perilaku. Dengan kata lain, semakin tinggi pendidikan maka semakin baik perilakunya, termasuk perilaku sadar melakukan pemeriksaan VCT khususnya pada kelompok berisiko seperti transpuan.

\section{c. Berdasarkan status penikahan}

Hasil penelitian diperoleh peneliti bahwa responden transpuan memiliki status dalam pernikahan yaitu belum menikah. Temuan ini tidak sejalan dengan penelitian Lubis pada tahun 2012 yang mana dalam penelitiannya peneliti menemukan bahwa mayoritas penderita HIV/AIDS dengan status sudah menikah.

Pendidikan kesehatan penting dilakukan terutama untuk kelompok transpuan agar tidak melakukan seks bebas dan hanya memiliki kesetiaan pada satu orang yang menjadi pasangannya. Pendidikan kesehatan sangat penting bagi wanita trans, dengan harapan dengan dilakukan VCT yang salah satunya adalah memberikan edukasi, maka kelompok transpuan yang telah mendapatkan informasi mereka tidak melakukan seks bebas dan setia pada pasangannya serta mau mengkonsumsi makanan yang bernutrisi baik.

\section{d. Berdasarkan pekerjaan}

Hasil penelitian diperoleh bahwa kelompok transpuan mayoritas berpenghasilan dan telah memiliki pekerjaan daripada yang belum memiliki pekerjaan. Hasil penelitian ini sejalan dengan penelitian Hutape, et al (2012) dimana dalam penelitiannya menyatakan penderita HIV/AIDS umumnya memiliki pekerjaan sebagai wiraswata. Salah satu faktor yang memperngaruhi kesehatan seseorang saat bekerja adalah lingkungan pekerjaannya. Salah satu aspek yang digali pada saat pengisian lembar formulir VCT adalah pekerjaan sehingga dengan data pekerjaan tersebut dapat diperoleh data detailterkait jenis pekerjaan dan risiko pekerjaan yang menyebabkan seorang individu dapat terkena HIV/AIDS.

\section{e. Berdasarkan sirkumsisi}

Hasil penelitian diperoleh oleh peneliti terkait sirkumsisi diperoleh hasil bahwa sebagian besar transpuan yang menjadi responden telah di sirkumsisi. Sunat atau khitan umum dilakukan masyarakat bukan disebabkan karena perintah agama saja bagi yang muslim tetapi juga karena alasan kesehatan. Menurut WHO (2013), sunat pada pria mengurangi risiko penularan HIV sekitar $60 \%$, mengingat sunat dikaitkan dengan infeksi HIV/AIDS. Sunat dapat mengurangi risiko penularan HIV pada laki-laki yang sering terpapar cairan penyebab HIV. Kelompok transpuan merupakan salah satu kelompok pengguna narkoba, terutama yang berisiko 
tertular HIV dan AIDS melalui pesta yang kelompok mereka adakan seperti bergantian jarum suntik dan seks bebas.

\subsection{Pengaruh VCT terhadap pengetahuan tentang asupan gizi}

Berdasarkan hasil penelitian diperoleh hasil ada pengaruh yang bermakna tingkat pengetahuan tentang asupan gizi sebelum dan setelah diberikan layanan VCT. Hal ini sejalan dengan penelitian Syahrir (2013), dengan hasil mayoritas pengetahuan yang baik tentang pemanfaatan VCT dimiliki oleh penderita dengan risiko tinggi terpapar HIV dan AIDS. Saat konseling VCT waktu yang tepat dalam pemberian informasi, termasuk dalam hal asupan gizi yang tepat untuk penderita HIV/AIDS. Asupan nutrisi yang tepat dapat meningkatkan kesehatan ODHA. Selain itu, nutrisi yang tepat membantu tubuh ODHA untuk mengabsorbsi dengan baik obat ARV yang di konsumsi, menjaga tubuh ODHA saat melakukan aktivitas fisik yang memerlukan energi yang cukup, meminimalkan penyakit oportunistik yang ditimbukan akibat CD4 yang menurun dan meningkatkan quality of life seorang ODHA. Asupan makanan yang tepat juga dapat mencegah malnutrisi dan memulihkan serta berat badan agar tidak terjadi penurunan dari berat yang semestinya akibat virus yang berada dalam tubuhnya. Pola makan ODHA juga disebabkan oleh asupan nutrisi yang dimakan sehari-hari. Pola konsumsi yang tidak memenuhi standar gizi yang baik menyebabkan infeksi HIV meluas serta dapat menyebabkan malnutrisi berat selama stadium AIDS dan predisposisi infeksi lain.

konseling gizi merupakan bagian integral dari pengelolaan gizi yang tidak dapat dipisahkan dari ODHA. Nasihat tentang literasi makanan dan minuman, kepekaan, dan rujukan untuk berbagai makanan dan minuman yang dapat meningkatkan malnutrisi, termasuk kehilangan nafsu makan, mual, muntah, metode penilaian diet yang dirangsang nafsu makan, dan asupan suplemen protein tinggi. Semua penderita AIDS memerlukan pendidikan tentang sistem kekebalan yang lemah yang memungkinkan penularan penyakit yang ditularkan melalui makanan, seperti angin topan, Clostridium botulinum, trikinosis, cacing pita, dan virus hepatitis A. Untuk mengatasi risiko tersebut, penting untuk mengetahui jenis, bentuk, proses, dan kualitas hadiah. Infeksi oportunistik yang ditularkan melalui terapi nutrisi diminimalkan. Perubahan bentuk, cara penyajian, dan suplemen makanan perlu diketahui ODHA.

Zat gizi, termasuk zat gizi makro dan zat gizi mikro, merupakan makanan esensial bagi penderita HIV/AIDS. Zat gizi utama adalah makanan yang didalamnya terdapat karbohidrat, protei dan lemak sedangkan zat gizi mikro adalah nutrisi yang mengandung mineral dan vitamin. Mikronutrien esensial untuk pertumbuhan dan perkembangan kekebalan, otot dan kerja tubuh, karena dapat mempercepat banyak proses dalam tubuh dan merupakan komponen penting dari organ-organ tertentu dalam tubuh. Orang yang terinfeksi HIV memiliki status gizi mikro yang cukup karena gizi mikro berperan penting dalam menunjang fungsi fisik. Asupan vitamin A dosis tinggi secara teratur telah terbukti mengurangi morbiditas atau mortalitas diare pada anak dari ibu yang terinfeksi HIV. Pemberian vitamin $\mathrm{E}, 800 \mathrm{mg} / \mathrm{hari}$, dan vitamin $\mathrm{C}, 1 \mathrm{~g} / \mathrm{hari}$ dapat mengurangi radikal bebas berlebih dalam tubuh dan mengurangi pajanan HIV pada orang dewasa yang terinfeksi HIV. 
Akibat asupan nutrisi pada bawah kebutuhan pasien terinfeksi HIV, mereka akan mengalami proteolisis lebih cepat pada pada tubuh. Di sini kita membutuhkan protein berdasarkan zat gizi mikro. Penderita HIV simtomatik (HIV stadium 3), bisa dicperoleh dari protein sebanyak $1,21,8 \mathrm{~g} / \mathrm{kg}$ berat badan/hari. Menurut sebuah penelitian \& surat keterangan lain, protein pula bisa diberikan dalam 1-1,4 g/kg berat badan/hari. Lemak di rekomendasikan untuk penderita HIV sama dengan llemak untuk orang sehat. Penderita HIV dengan IO diare, lemak pada minyak kelapa, galat satu produk lemak terbaik, dipercaya menaikkan penyerapan lemak, buang air besar dan tanda-tanda gangguan gastrointestinal lainnya. Minyak ikan yang diambil menggunakan minyak kelapa terbukti efektif untuk menaikkan fungsi kekebalan tubuh lantaran bisa mengurangi peradangan yang terjadi dalam tubuh penderita HIV.

Penilaian status gizi sejak pasien memulai pengobatan harus dilakukan sebagai bagian dari pengobatan dan skrining awal untuk mengidentifikasi risiko malnutrisi. Status gizi dapat dinilai secara antropometrik, biokimiawi dan klinis. Pasien yang terinfeksi HIV sering mengalami gangguan penyerapan nutrisi, yang menyebabkan penurunan fungsi biologis tubuh. Perubahan status klinis pasien tidak hanya sebagai akibat dari masalah asupan nutrisi, tetapi juga sebagai akibat dari proses penyakit yang cenderung menjadi kronis.

\subsection{Pengaruh VCT terhadap pengetahuan tentang perilaku seksual berisiko}

Berdasarkan hasil penelitian diperoleh bahwa terdapat pengaruh tingkat pengetahuan tentang perilaku seksual berisiko sebelum dan setelah diberikan layanan VCT pada kelompok transpuan. Hal ini sesuai dengan penelitian yang menyatakan bahwa salah satu penyebab rendahnya pengetahuan dan kesadaran akan masalah seksual adalah kurangnya informasi di kalangan remaja tentang perilaku seksual atau kesehatan reproduksi (Yaunin, dkk, 2016).

Penelitian ini konsisten dengan penelitian Adedimeji, Adebora et al. (2019) Pengetahuan responden tentang HIV/AIDS ditemukan tidak mencerminkan pengetahuan mereka secara keseluruhan tentang penyakit menular seksual lainnya seperti gonore, sifilis, klamidia, dan kutil dubur. Saat ditanya/diperiksa nama-nama penyakit menular seksual lain yang diketahui responden, hanya separuh responden yang memiliki pengetahuan yang sama tentang penyakit menular seksual, seperti gonore, sifilis, dan kutil kelamin. Ini menunjukkan bahwa sumber mereka didasarkan pada pengalaman pribadi atau pengetahuan sebelumnya bahwa mereka mungkin atau mungkin pernah memiliki hubungan IMS tertentu.

Hal ini juga sesuai dengan penelitian Ramanathan (2013), dimana kelompok LSL yang menggunakan kondom dengan tidak konsisten dan berganti pasangan masih relatif tinggi berisiko terjadi penularan HIV dan penyakit menular seksual lainnya. Penelitian tentang dampak penggunaan kondom terhadap pencegahan IMS yang dilakukan Amina (2015) di wilayah kerja Puskesmas Sangkrah Surakarta menunjukkan tingkat penyalahgunaan alat pengaman (kondom) karena risiko penularan HIV Masu (71,4\%) . ) Dan satu-satunya persentase yang baik adalah $(28,6 \%)$.

Herlani N di Kota Semarang tentang Perilaku Seksual Berbahaya HIV/AIDS Pada Kelompok Homoseksual, Riyanti, E., Widjanarko, B., sebuah penelitian pada (2016) menemukan bahwa semua subjek tidak dapat meninggalkan kebiasaan 
mereka, semua subjek dengan seks berbahaya merespons dengan baik proposal untuk menggunakan kondom, tetapi pada kenyataannya tidak seperti yang diharapkan. Hanya beberapa orang yang ingat satu sama lain dan menggunakan kondom selama hubungan seksual, dua dari delapan, satu subjek secara sukarela menggunakan kondom, dan yang lain merasa tidak nyaman dengan kondom yang dilepas, saya tidak ingin menggunakannya karena saya merasakannya. Menerima komunitas dan mengetahui riwayat seksual pasangannya.

Seorang transpuan yang pernah melakukan hubungan seks berisiko terkadang cenderung menunda datang ke klinik VCT karena enggan mencari layanan VCT karena merasa tidak berisiko tertular HIV/AIDS. Beberapa kendala yang mereka hadapi juga menjadi faktor penghambat kelompok transpuan dalam menggunakan layanan klinik VCT secara memadai, seperti biaya, malu, kemalasan, dan miss informasi tentang layanan VCT. Namun, beberapa pasien cenderung pergi ke klinik VCT karena takut tertular HIV. Pasalnya, ada informasi tentang sesama transpuan dengan gejala HIV/AIDS yang mirip dengan dirinya, dan ia langsung mencari pertolongan medis di klinik VCT.

Kesadaran yang rendah dikaitkan dengan persepsi responden tentang seks yang lebih aman (misalnya, menggunakan kondom dan tidak berganti pasangan). Transpuan tidak memiliki pasangan seks melakukan hal yang sama karena mereka cenderung memiliki lebih dari satu pasangan dalam hubungan seksual berisiko, seperti berganti pasangan seks. Tidak ada jaminan bahwa menggunakan kondom akan mencegah infeksi HIV. Kondom memiliki lubang yang hanya memberikan perlindungan 46-76\% terhadap virus HIV. Artinya, seseorang yang pernah melakukan hubungan seks tidak aman tetap berisiko tertular HIV meskipun menggunakan kondom.

Kesadaran kelompok transpuan yang tetap mengutamakan pengobatan daripada pencegahan juga menjadi salah satu faktor yang dapat menyebabkan rendahnya upaya pencegahan. Kelompok ini cenderung mencari pengobatan (perawatan medis) ketika gejala muncul karena mereka telah melakukan hubungan seksual berisiko.

\section{Kesimpulan}

Layanan VCT yang baik akan mempengaruhi pengetahuan tentang asupan gizi dan perilaku seksual berisiko pada kelompok transpuan. Diharapkan layanan VCT meningkatkan mutu layanan konselor yang profesional terutama terkait gizi dan perawatan pada penderita HIV/AIDS khususnya pada kelompok transpuan sehingga mempermudah berkomunikasi dengan kelompok tersebut serta penderita bisa ikut secara aktif dengan LSM, swasta maupun pemerintah guna pembinaan dalam upaya pencegahan peningkatan prevalensi HIV/AIDS.

\section{Daftar Pustaka}

Carmelita, D. et al. (2017). Analisis Faktor-Faktor yang Berhubungan Dengan Praktik Skrining IMS Oleh Lelaki Seks Lelaki (LSL) Sebagai Upaya Pencegahan Penularan HIV (Studi Kasus Pada Semarang Gaya Community). Jurnal Kesehatan Masyarakat, 5(3), pp. 486-495.

ConQ.me. (2015). Lgbt Survey Edisi 1 Demografi Psikografi: ConQ.

Dewi, Prima \& Hardianah. (2014). Virologi mengenal virus penyakit dan pencegahannya. Yogyakarta: Nuha Medika. 
Herlani, N., Riyanti, E., Widjanarko, B. (2016). Gambaran Perilaku Seksual Berisiko HIV/AIDS Pada Pasangan Gay Di Kota Semarang. Jurnal Kesehatan Masyarakat, 4 (3), pp. 1059-1066.

Hutapea, D.M., Sarumpaet, S.M. \& Rasmaliah, (2012). Karakteristik Penderita HIV/AIDS Di Klinik VCT Rumah Sakit Umum HKBP Balige. 10(2), pp. 20-27. https://doi.org/10.35960/vm.v10i2.363

Kemenkes RI. (2018). Situasi Umum HIV/AIDS dan Tes HIV.

Kementerian Kesehatan Republik Indonesia. (2021). Infodatin HIV/AIDS.

Lubis, Z.D. (2012). 'Gambaran karakteristik individu dan factor risiko terhadap terjadinya infeksi oportunistik pada penderita HIV/AIDS di Rumah Sakit Penyakit Infeksi Sulianti Saroso tahun 2011' skripsi tidak dipublikasikan. Universitas Indonesia.

Luthfiana, Y. (2012). Hubungan pengetahuan dan sikap terhadap perilaku berisiko HIV/AIDS pada pekerja bangunan proyek World Class University tahun 2012', skripsi tidak dipublikasikan. Universitas Indonesia.

Rahmartani LD, Olam SJ. (2012) Buku suplemen bimbingan teknis kesehatan reproduksi infeksi menular seksual dan HIV/AIDS. Jakarta: BKKBN dan UNESCO Jakarta.

Ramanathan, S., (2013). Consisten Condom Use With Regular, Paying and Casual Male Partners and Asociated Factors Men Who Have Sex With Men In Tamil Nadu, India. BMC Public Health. India.

Syahrir, W. (2013). Faktor yang berhubungan dengan pemanfaatan voluntary counseling and testing (VCT). skripsi tidak dipublikasikan. Universitas Hasanudin.

Notoatmodjo. (2017). Promosi Kesehatan dan Ilmu Perilaku. Jakarta: Rineka Cipta.

Wardani, dkk. (2020). Studi perilaku seks menyimpang terhadap kejadian hiv fase laten pada komunitas lelaki seks lelaki (LSL) di LSM Kompeda Surabaya. Jurnal Keperawatan dan Kesehatan Masyarakat Cendekia Utama. 9(1). pp. 93-101. https://doi.org/10.31596/jcu.v9i1.519

WHO. (2013). HIV/AIDS. http;//www.who.int/ features/qa/71/en. Diakses pada 27 Agustus 2021.

Yaunin Y, Lestari Y. (2016). Faktor-Faktor yang Berhubungan dengan Perilaku Seksual Remaja di Kota Padang. 5(2). pp. 448-55. 